\title{
SOME PECULIARITIES OF THE MOUTH PARTS AND OVIPOSITOR OF CICADA SEPTENDECIM.
}

\author{
Professor J. D. Hyatt, New Rochelle, N. Y.
}

The year 1894 , being the seventeenth since the last appearance of this insect in the vicinity of New York, the 25th of May seems to have been the day unanimously agreed upon by the broods in this neighborhood to leave their subterranean abodes and emerge to the light of day.

Although some skirmishers were seen in the woods a day or two before, and many camp followers continued to appear above ground after that date, yet the main army consisting of incalculable myriads came forth on the night preceding the $25^{\text {th }}$ day of May, and for several weeks they swarmed in certain localities, over the trees, shrubs and foliage of all kinds.

It is not my purpose to describe this curious insect, or its habits, as such description with its life history may be found in any elementary work on entomology, but during its prevalence alarming reports were frequently made in the newspapers of the great damage done to crops, and to fruit and forest trees, by the seventeen-year locust, and as nobody contradicted these statements, the newspaper reporters manufactured and published circumstantial accounts of persons, preferably children, who had lost their lives by being bitten or stung by these "venomous insects." While fully aware that these reports were purely imaginary and sensational, my curiosity was stimulated to make a microscopical examination of the "biting and stinging" organs of Cicada, an additional motive being the opportunity, which occurs at such long intervals, of obtaining abundant material for the study.

It is hardly necessary to say that after handling and examining hundreds of specimens, and carefully studying their habits, I found no evidence that they ever bite or sting, or that after 
reaching the winged state they ever do the slightest injury to vegetation of any kind, but as I had never seen a description of the microscopical appearance of the mouth parts and ovipositor, I spent much time in making a careful examination of them, the sections notably showing some curious features.

As this insect belongs to the natural order Hemiptera, the mouth parts in a general way are typical of that order, the mandibles and maxillæ being drawn out into greatly lengthened stylets or setæ and enclosed in the labium.

Fig. I represents the extremity of the labium enclosing the four slightly projecting stylets, x I 20.

( To show the lengths of these parts under the same amplification, it would be necessary to make the drawing 30 inches long.)*

The outer hooked pieces serve as anchors, which being inserted into the tissues of a plant afford a leverage for forcing in the two central stylets, which together form a sucking tube.

Fig. 2 is a transverse section through the labium and the four stylets, showing the very curious manner in which a tube is formed by holding in juxtaposition the two inner grooved pieces and closing the laps by the outer pieces of the same sectional form, all being held firmly together by the muscular labium which is closely wrapped around them. This will be easily understood by an inspection of sections of the four stylets as seen in the lower figures.

While the mouth parts of Cicada are perfectly adapted to the purpose of sucking the juices of plants, yet in the examination of thousands that I have seen upon cherry, pear and other trees I have never been able to discover one in the act of feeding, either on the fruit or foliage.

The ovipositor is the instrument used by the female for making incisions in the twigs of trees in which to deposit her eggs. It consists of three parts, the two outer ones being tubular with an opening near the extremity, through which the eggs are extruded into the channel cut for their recuption. They are

*(The original drawings were reduced one-third by the engraver.-ED.) 
pointed at the ends, and a little anterior to the extremity are somewhat enlarged and set with sharp teeth like a rasp, which extends spirally around the teeth pointing backwards.

Fig. 3 represents one of these saws, $a$ being the outlet of the oviduct which opens inward or toward the central piece.

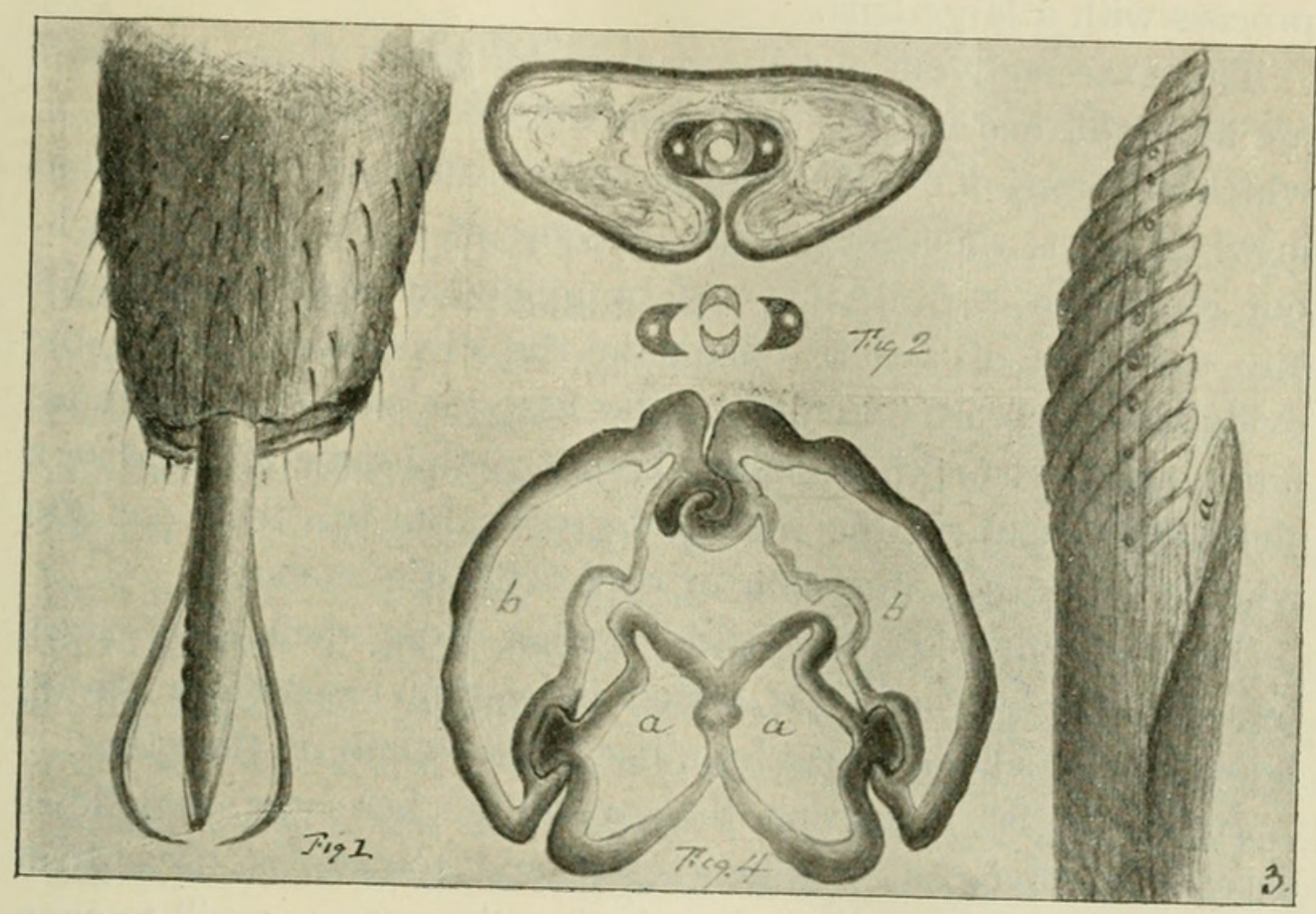

The central piece which serves to hold the two ovipositor saws in place and guide them in their movements, ends in two extremely sharp points slightly curved outward. The insect in cutting the channel for her eggs closes her legs around the twig and forcing in the ovipositer saws beneath the bark and into the soft sap wood, works them rapidly backward and forward cutting loose but not removing the wood fiber. In doing this the outward curves of the central piece causes the saws to spread so that she cuts at the same time two channels, which diverge from the entrance, leaving a ridge of solid wood between the two, nearly a tenth of an inch wide at the extremity, while the channels closely approximate at the entrance.

After finishing the cut, which is about three-tenths of an inch in length, she withdraws the ovipositor, and forcing it in the 
first entrance to the greatest depth proceeds to deposit the eggs, which are placed very symmetrically in pairs obliquely to the middle partition, a little cavity being cut for each egg, into which it exactly fits. The eggs are about 15 in number on each side.

As these insects are not at all timid, I was able to watch this process with a large lens.

The extremely curious mechanism by which these processes are accomplished will be easily understood by inspecting Fig. 4, which is a section of the three pieces constituting the ovipositer, in which $a a$ is the central piece, having on each side, throughout its length, a projecting rail or guide-bar which exactly fits into a groove of similiar shape in the ovipositor; $b b$ are the oviducts, which are bounded on the exterior side by a chitinous frame, and have for their interior boundary the same material for a short distance above the $T$-shaped groove, but this thins out into what is evidently a muscular or contractile tissue above.

The two ovipositors are held together along their outer edges by a peculiar pair of folds, which in section resemble a strong hook on one side, grasped by a hand and thumb on the other.

As the insect, in cutting the groove for her eggs, sometimes spreads her ovipositors widely apart, and sometimes uses them close together, it is evident that she has the power at will to open the hand seen on the left, or close it in the hook, as the particular stage of the process may require. 


\section{$2 \mathrm{BHL}$ Biodiversity Heritage Library}

Hyatt, J D. 1896. "Some Peculiarities of the Mouth Parts and Ovipositor of Cicada septendecim." Transactions 17, 111-114.

View This Item Online: https://www.biodiversitylibrary.org/item/86837

Permalink: https://www.biodiversitylibrary.org/partpdf/90821

\section{Holding Institution}

University of Toronto - Gerstein Science Information Centre

\section{Sponsored by}

University of Toronto

\section{Copyright \& Reuse}

Copyright Status: Not provided. Contact Holding Institution to verify copyright status.

This document was created from content at the Biodiversity Heritage Library, the world's largest open access digital library for biodiversity literature and archives. Visit BHL at https://www.biodiversitylibrary.org. 